\title{
The Opening of Neo-Tethys and the Formation of the Khuff Passive Margin
}

\author{
Andy Bell (Shell <Andy.Bell@Shell.com>) and Pieter Spaak (Shell)
}

\begin{abstract}
Any investigation of regional geology and palaeomagnetism in the Middle East will show that in the Permian a series of terranes separated from Gondwana and drifted north, opening the Neo-Tethys Ocean in their wake. To the north of these terranes, the Palaeo-Tethys Ocean closed and was largely subducted. Eventually in a non-synchronous movement but largely in Late Triassic and Early Jurassic times, these terranes docked with the northern margin of the former Palaeo-Tethys during the Cimmerian Orogeny.
\end{abstract}

The opening of the Neo-Tethys in Arabia does not follow the classic pattern of continental break-up resulting in oceanic crust. Classically we should expect thermal up-doming, followed by the onset of syn-rift deposition, frequently but not always associated with volcanism. The formation of en-echelon systems of rotated fault blocks are also characteristic, followed by a break-up unconformity and the formation of the first oceanic crust. What we see in Arabia as a consequence of the opening of NeoTethys exhibits few of these features. Distinguishing thermal up-doming from the uplift associated with the 'Hercynian' event in Arabia, coupled with the glacial sculpting of the PermianCarboniferous Unayzah Formation is fraught with difficulty. Although locally volcanics of Permian age are known from Oman, they are absent over most of Arabia.

The real difference with the classic view of rifting, however, is the almost complete absence of rotated fault blocks with associated thickened sections of syn-rift sediments. While it is possible that some of the features have been obscured by glacial-related features or lie outboard of the Arabian Peninsula and currently underlie the Zagros, it is unlikely to be the only reason for their apparent absence. By analysing the subsidence histories of points along the Arabian margin and detailing the isopachs of the Permian and Triassic sediments it is possible to interpret a different model of continental break-up that has exploited possibly older weaknesses in the crust and allowed a "soft" separation of the Cimmerian terranes. This opening style has significant implications for the play development; not only for the morphology of reservoir bodies and structures, but also for the thermal and structural history of this section of the Tethyan margin 